\title{
ISOLASI DAN KARAKTERISASI BAKTERI INDIGENOUS (Bacillus Cereus FRANK.) SEBAGAI AGENSIA PENGENDALI HAYATI HAMA KUBIS
}

\author{
ISOLATION AND CHARACTERIZATION INDIGENOUS BACTERIA (Bacillus Cereus \\ FRANK.) FOR AGENT AGAINST CABBAGE
}

\author{
Christina L. Salaki \\ Jurusan Hama dan Penyakit Tumbuhan, Fakultas Pertanian Unsrat,Manado_ 95115. \\ e-mail : Christinasalaki@ymail.com .
}

\begin{abstract}
B. cereus strains were isolated from three district of North Sulawesi. The B. cereus strains are potential indigenous bacteria for biological control agent against $P$. xylostella. The $B$. cereus strains were isolated using Ohba and Aizawa methods. Two hundred and two isolates putatively were isolated and identified as member of species $B$. cereus. Subseguently, representing isolates were selected to be screened for the ability to kill $P$. xylostella. The screening test was conducted by using leaf depped methods with the concentration of $1,22 \times 10^{8} \mathrm{spore} / \mathrm{ml}$. The potential to kill test insect was assessed by mortality value. The result indicated that 10 isolates out of 15 of could produce mortality of insect from 50 to $100 \%$ after exposure of 96 hours. It was confirmed that based on symptoms produced as well as bacterial characteristics reisolated from cadaver of test insect, the death of the test insects was certainly caused by application of bacterial isolates. It could be concluded that indigenous bacterial isolates identified to be member of $B$. cereusare potential for biological control agent against $P$. xylostella.
\end{abstract}

Keywords: Indigenous bacteria, Bacillus cereus, Plutella xylostella

\begin{abstract}
ABSTRAK
Untuk memperoleh bakteri yang berpotensi sebagai agensia pengendali hayati hama Plutela.xylostella dilakukan isolasi dan karakterisasi bakteri indigenous. (Bacillus cereus) yang diperoleh dari sampel tanah yang berasal dari tiga kabupaten di Sulawesi utara. Bakteri diisolasi dengan metode Ohba dan aizawa. Dari 103 sampel tanah yang digunakan dapat diperoleh 202 isolat yang diidentifikasi sebagai anggota spesies B.cereus. Sebanyak 15 isolat dipilih untuk mewakili seluruh isolat dalam sereening uji kemampuan membunuh P.xylostella. Pengujian dilakukan dengan metode pencelupan daun (leaf dipped method) pada konsentrasi $1,22 \times 10^{8}$ spora/ml. Kemampuan membunuh serangga uji dinyatakan dengan nilai mortalitas setelah pendedahan selama 96 jam. Ternyata hanya 10 isolat yang dapat menimbulkan mortalitas serangga uji dengan kisaran 50\%-100\%. Berdasarkan gejala penyakit yang muncul, karakteristik bakteri hasil reisolasi dari cadaver serangga mati menunjukkan bahwa kematian serangga uji dipastikan disebabkan oleh isolat bakteri yang diberikan. Disimpulkan, bahwa isolat bakteri indigenous anggota spesies B.cereus yang diperoleh berpotensi untuk dikembangkan menjadi kandidat agensia pengendali hayati bagi serangga hama kubis P.xylostella.

Kata kunci: Bakteri Indigenous, Bacillus Cereus, Plutella Xylostella
\end{abstract}

Eugenia Volume 17 No. 1 April 2011 


\section{PENDAHULUAN}

Peningkatan produksi kubis menjadi satu hal yang penting untuk dilakukan baik dalam segi kuantitas maupun kualitas. Produksi kubis untuk provinsi Sulawesi Utara dari tahun 2006 sampai tahun 2010 adalah 11,289 ton/tahun, 13.559 ton/tahun, 17.858 ton/tahun, 31.575 ton/tahun dan 23.586 ton/tahun (Badan Pusat Statistik dan Direktorat Jenderal Hortikultura, 2011). Penurunan kuantitas dan kualitas produksi kubis tahun 2009 dan 2010, dapat disebabkan oleh adanya serangan hama dan penyakit

Plutella xylostella merupakan salah satu hama penting pada tanaman kubis. Selain kubis, $P$. xylostela menjadi hama beberapa varietas kubis dan beberapa tanaman dari familia. Cruciferae termasuk lobak, sawi dan bunga kol (Harjaka dan Suryanti, 2002; Hastuti, 2003; Wikipedia, 2011). Kerusakan yang dihasilkan sangat khas, pada daun akan terbentuk suatu lubang dengan diameter 0,5 $\mathrm{cm}$ sehingga daun berlubang-lubang dan apabila serangan cukup berat, tanaman kubis gagal membentuk krop dan gagal panen (Rueda dan Shalton, 2006).

Upaya pengendalian larva $P$. xylostella sampai saat ini masih sering dilakukan dengan penggunaan insektisida kimiawi. Penggunaan insektisida kimiawi baik dalam bidang kesehatan maupun pertanian secara terus menerus tanpa melihat kondisi ekosistem terbukti menimbulkan dampak negatif, yaitu terjadinya resistensi hama dan serangga vektor, resurgensi hama, ledakan hama sekunder, pencemaran lingkungan, dan terakumulasi dalam tanaman, sehingga berbahaya bagi manusia dan berbagai spesies hewan yang memakannya (Untung, 1996; Sembel, 2010). Kekhawatiran akan dampak negatif tersebut menimbulkan kebutuhan akan adanya alternatif baru yang dapat dipakai untuk mengendalikan populasi hama sampai pada tingkat yang tidak merugikan secara ekonomi.

Pengendalian dengan menggunakan musuh alami dirasa sangat baik dan aman karena tidak menimbulkan pencemaran lingkungan. Penggunaan patogen, terutama bakteri dipandang sangat baik dalam pengendalian hama berwawasan lingkungan. Bakteri $B$. cereus adalah salah satu agensia patogen yg mempunyai potensi besar untuk digunakan sebagai pengendali hayati. Bakteri ini mempunyai inang yang spesifik, tidak berbahaya bagi musuh alami hama dan organisme non target lainnya, mudah terbiodegradasi oleh lingkungan serta dapat dinaikkan patogenisitasnya dengan teknik rekayasa genetika (Khetan, 2001).

Beberapa strain $B$. cereus yang patogenik telah dikembangkan untuk mengendalikan serangga hama diantaranya strain $\operatorname{Pr} 1017$ yang diisolasi dari larva Pristiphora erichsonii yang sakit (Heimpel dan Angus, 1963), strain Cm 1-3 yang di isolasi dari ulat Carpocapsa pomonella yang sakit dan strain BP01 yang berasal dari tanah di Amerika Serikat (Anonim, 1992; Anonim, 1999; Anonim, 2000). Di samping digunakan dalam mengendalikan hama, B. cereus digunakan juga untuk mengendalikan penyakit tanaman seperti B.cereus strain W35 (Anonim, 2000). Binoto (2001) menemukan strain B.cereus yang diisolasi dari serangga sakit dan diuji terhadap larva Crocidolomia binotalis. Dengan demikian, dapat diperkirakan bahwa strain-strain $B$. cereus dan bakteri entomopatogenik lainnya dapat diisolasi dari berbagai tempat di seluruh kepulauan Indonesia.

Mengingat sifat-sifat unggul bakteri pembentuk spora tersebut untuk dijadikan sebagai agensia pengendali hama dan vektor penyakit, perlu dilakukan pencarian bakteri-bakteri spesifik untuk lebih mengungkap kekayaan biotik Indonesia dan kemudian dimanfaatkan sebaik-baiknya. Bakteri tersebut kemudian perlu diuji patogenisitasnya terhadap berbagai jenis hama dan vektor penyakit karena strain-strain bakteri ini patogenik spesifik hanya terbatas pada jenis-jenis hama tertentu saja.

Bakteri B. cereus merupakan jenis patogen yg sangat toksik terhadap hama-hama tertentu seperti $P$. xylostella, namun aman terhadap organisme bukan sasaran sehingga tidak mencemari lingkungan (Wikipedia, 2011).

Pada penelitian ini perlu dilakukan pengujian bakteri tanah $B$. cereus untuk mengetahui patogenisitasnya terhadap larva $P$. xylostella yang merupakan salah satu hama 
penting tanaman kubis di Indonesia. Tujuan penelitian adalah untuk memperoleh isolat bakteri $B$. cereus dari tanah yang berpotensi sebagai pengendali hayati hama $P$. xylostella

\section{METODE PENELITIAN}

\section{Tempat dan Waktu Penelitian, Alat dan Bahan}

Penelitian ini dilaksanakan di

Laboratorium Jurusan Hama dan Penyakit Tumbuhan Fakultas Pertanian. Waktu pelaksanaan bulan Oktober 2010 sampai dengan Maret 2011. Bahan dan alat yang digunakan antara lain laminar flow, water bath, vortex, incubator, mikroskop, tabung reaksi, petridish, pipet, labu erlenmeyer, media NA, tanah dan aquades steril.

\section{Metode Penelitian \\ Isolasi Bakteri B. cereus}

Sampel tanah di koleksi dari tiga kabupaten di Sulawesi Utara (Kabupaten Minahasa Selatan, Minahasa dan Kota Tomohon) pada areal pertanian, kebun, sawah dan tempat-tempat tertentu yang diduga mengandung endospora bakteri. Isolasi bakteri dilakukan di laboratorium dengan metode Ohba dan Aizawa (1979) pada Media Kultur NA (Nutrien agar). Identifikasi Isolat B. cereus Berdasarkan Morfologi Koloni dan Morfologi sel. Ciri-ciri sel bakteri meliputi bentuk sel, sifat gram bakteri, bentuk spora. Ciri-ciri sel bakteri digunakan untuk mengidentifikasi isolat sebagai anggota $B$. cereus. Biakan bakteri yang selnya berbentuk batang, mempunyai sifat gram positif, motil, mempunyai spora, ditumbuhkan pada medium nutrien agar pada cawan petri untuk melihat morfologi koloninya.3. Perbanyakan $P$. xylostella Larva $P$. xylostella sebagai bahan penelitian diperoleh dengan mengumpulkan larva dari kebun kubis, kemudian dipelihara dan diperbanyak di laboatorium. Untuk memperoleh larva dalam jumlah yang cukup, perbanyakan dilakukan dengan menggunakan daun kubis yang masih segar sebagai pakannya. Penggantian pakan dilakukan setiap hari sampai larva menjadi pupa. Selanjutnya pupa dimasukkan dalam kurungan kasa. Di dalam kurungan telah disiapkan tanaman kubis muda (umur 3-4 minggu) untuk tempat meletakkan telur bagi serangga imago (ngengat). Ngengat diberi pakan larutan madu 10\% yang dioleskan pada kapas yang digantung dalam kurungan kasa. Pemberian madu diberikan setiap hari. Setelah ngengat menghasilkan sejumlah telur pada tanaman, lalu tanaman dipindahkan ke kurungan lain, selanjutnya ditunggu hingga telur menetas dan larva berkembang menjadi instar III. Larva-larva diseleksi untuk mendapatkan larva yang homogen dari segi ukuran dan umur yang akan di pakai sebagai larva uji.4. Uji Daya Bunuh Uji daya bunuh bertujuan untuk mengetahui kemampuan bakteri menginfeksi dan menimbulkan kematian larva $P$. xylostella, dengan jumlah spora tertentu pada batas kisaran yang dipandang potensial sampai virulen, tergantung dari besarnya persentase kematian larva uji. Pada pengujian ini, konsentrasi spora yang digunakan adalah $1,22 \times 10^{8}$ spora/ml dengan menggunakan metode pencelupan daun (leaf dipped method). Pengamatan dilakukan pada 24,48,72 dan 96 jam setelah perlakuan. Perkembangan gejala penyakit pada serangga uji dicatat mulai awal pengujian sampai serangga uji mati. Jumlah inidividu yg mati dicatat untuk perhitungan mortalitas.

\section{HASIL DAN PEMBAHASAN}

\section{Hasil Isolasi Bakteri B. cereus}

Hasil isolasi dari 103 sampel tanah yang diambil dari tiga kabupaten di Provinsi Sulawesi Utara adalah sebanyak 202 isolat bakteri pembentuk spora (Tabel 1). Berdasarkan ciri-ciri morfologi koloni dan sel, diidentifikasi sebagai anggota spesies $B$. cereus. Pertumbuhan bakteri pada media biakan menunjukkan, bahwa morfologi koloni isolat-isolat tersebut adalah berbentuk ireguler, permukaan koloni kasar, datar, dan agak mengkilap. Warna koloni putih kekuningan (gambar 1a). Hal ini sesuai dengan yang dikemukakan oleh Tay et al., (1982). B. cereus dapat tumbuh dengan baik pada media NA yang diinkubasi di laboratorium yang mempunyai suhu rata-rata $28,8^{\circ} \mathrm{C}$. Menurut Gordon et al., (1973) B. cereus dapat tumbuh dengan baik pada suhu maksimum $35^{\circ} \mathrm{C}$ sampai $45^{\circ} \mathrm{C}$ dan suhu minimum $10^{\circ} \mathrm{C}$ sampai $20^{\circ} \mathrm{C}$. Permukaan koloni $B$. cereus yang tumbuh 
pada media NA tampak mengkilap dan dapat memantulkan cahaya busuk (Binoto, 2001).

Pada umur satu hari spora belum terbentuk. Spora baru terlihat setelah pengamatan 48 jam setelah inokulasi. Spora tampak lisis pada pengamatan 96 jam setelah inokulasi. Hal ini ditunjang untuk pendapat yang dikemukakan oleh Gordon et al., (1973) bahwa spora B. cereus mengalami perkembangan yang nyata pada umur 48 sampai 168 jam setelah inokulasi. Spora $B$. cereus terdapat pada bagian para sentral, berbentuk elips dan berwarna putih. Pada Tabel 1 dapat dilihat bahwa jumlah isolat bakteri $B$. cereus yang diperoleh berbeda untuk setiap kabupaten. Perbedaan ini disebabkan di daerah tertentu pencarian dilakukan lebih intensif dibandingkan dengan daerah lainnya. Sebenarnya diperlukan pengambilan sampel berulang kali, karena penemuan bakteri entomopatogenik pada suatu saat tertentu dipengaruhi oleh banyak faktor antara lain hujan dan erosi, epizootik dan endozootik, dan ada kemungkinan pada suatu saat ditemukan bakteri entomopatogenik di suatu tempat tertentu, tetapi pada saat lain tidak dapat ditemukan lagi dan sebaliknya.

\section{Uji Daya Bunuh}

Uji daya bunuh dilakukan pada sebagian isolat yang mewakili tiap kabupaten. Dari hasil

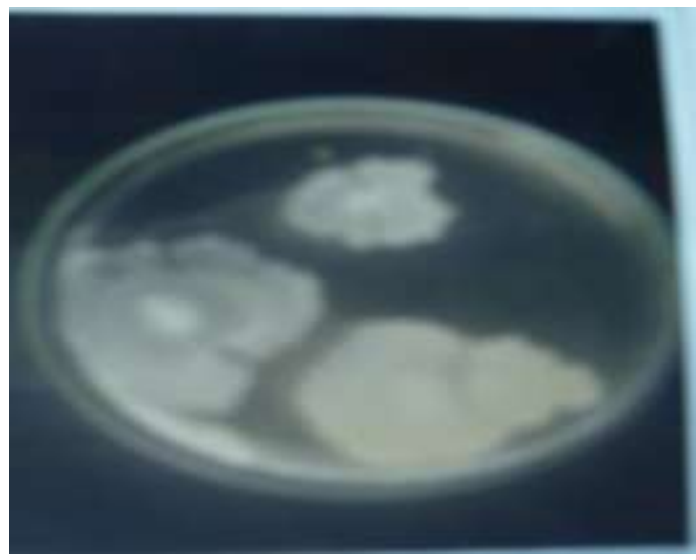

(a) pengamatan morfologi koloni dan sel dipilih 15 isolat yang diuji pada taraf pendahuluan terhadap larva P. xylostella. Hasil pengujian disajikan pada Tabel 2. Dari hasil pengujian semua isolat bakteri tersebut terdapat 10 isolat yg dapat menimbulkan penyakit dan mematikan larva $P$. xylostella $>50 \%$ setelah 96 jam dengan dosis inokulum $1,22 \times 10^{8}$ spora/m.

Gejala yang ditimbulkan setelah memakan pakan yang diberi perlakuan adalah terjadinya perubahan perilaku ulat. Ulat yang terinfeksi bergerak menjauhi pakan atau kehilangan nafsu makan, gerakan menjadi lambat, kotoran (faces) agak cair atau diare, dan akhirnya mati, warna tubuh menjadi kehitam-hitaman dan tubuhnya lembek. Bila disentuh kulit ulat akan pecah dan mengeluarkan cairan berwarna hitam dan berbau busuk. Timbulnya warna hitam disebabkan karena bakteri telah sampai ke bagian haemocol sehingga sel-sel darah keracunan (Poinar dan Thomas, 1981).Ternyata mortalitas tertinggi terdapat pada konsentrasi $1,22 \times 10^{8}$ spora $/ \mathrm{ml}$ yang dapat membunuh sampai $100 \%$ larva (Tabel 2). Untuk mengetahui lebih jelas mengenai daya bunuh isolat-isolat tersebut perlu dilakukan pengujian secara kuantitatif dengan konsentrasi yang lebih bervariasi dari yang rendah sampai pada yang lebih tinggi sehingga dapat ditentukan patogenisitasnya yang diekspresikan dengan nilai $\mathrm{LC}_{50}$ dan $\mathrm{LC}_{90}$ masing-masing isolat.

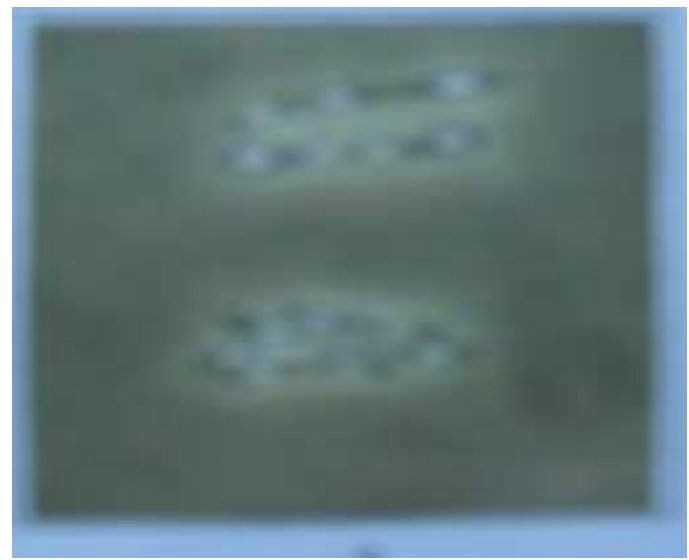

(b)

Gambar 1. Morfologi Koloni (a) dan Morfologi sel (b) Isolat yang Diidentifikasi sebagai Anggota B. cereus (Figure 1. Colonial Morphology (a) Cell Morphology (b) of Bacterial Isolates Identified as B. cereus) 
Tabel 1: Jumlah Sampel Tanah dan Isolat B.cereus dari Berbagai Kabupaten di Sulawesi Utara (Table 1 Number of Soil Samples and Isolates of B. cereus from Various Districts in North Sulawesi)

\begin{tabular}{ccc}
\hline Lokasi & Jumlah Sampel & Jumlah Isolat B. cereus \\
Kabupaten & Tanah & 37 \\
Minahasa Selatan & 17 & 111 \\
Minahasa & 70 & 54 \\
Kota Tomohon & 16 & 202 \\
\hline Total & 103 & \\
\hline
\end{tabular}

Tabel 2. Hasil Pengujian Bakteri B. cereus terhadap larva P. xylostella (Table 2. Result of B. cereus Isolate test on Larva of P. xylostella)

\begin{tabular}{llll}
\hline No & Kode Isolat & Kabupaten & Mortalitas (\%) \\
\hline 1 & PPT & Minahasa Selatan & 36,7 \\
2 & RNP & Minahasa Selatan & 86,7 \\
3 & MTC & Minahasa Selatan & 56,7 \\
4 & TEK & Minahasa Selatan & 30,0 \\
5 & LBH & Minahasa Selatan & 83,3 \\
6 & NOH & Minahasa & 70 \\
7 & ATP1 & Minahasa & 63,3 \\
8 & SDR2 & Minahasa & 40,0 \\
9 & RWK1 & Minahasa & 93,3 \\
10 & SDK1 & Minahasa & 40,0 \\
11 & PPT & Minahasa & 86,7 \\
12 & TDR & Minahasa & 90,0 \\
13 & RRK & Tomohon & 33,3 \\
14 & RRO & Tomohon & 76,7 \\
15 & RRW & Tomohon & 100 \\
\hline
\end{tabular}

\section{KESIMPULAN}

Pada penelitian ini telah ditemukan 202 isolat $B$. cereus. Namun dari 15 isolat yang diuji hanya 10 isolat yang dapat membunuh larva $P$. xylostella dengan mortalitas berkisar antara 50 $100 \%$ dalam waktu empat hari (96 jam). Penelitian ini sangat penting dan memberi harapan untuk menemukan isolat yang patogenisitas spesifiknya tinggi terhadap berbagai serangga hama lain dan serangga vektor penyakit.

\section{DAFTAR PUSAKA}

Anonim, 1992. Bacillus cereus and other Bacillus spp.

http:/vm.cfsan.fda.gov/ mow/chap12.html. Diakses tgl. 10 Juni 2011

-------, 1999. Bacillus cereus Strain BP01. http://www.epa.gov/pesticided/ biopesticides/ factsheets/ fs119802e.html. Diakses tgl.10 Juni 2011.

Anonim, 2000._Bacillus cereus Strain W35. http://www.wisc.edu/warf.boi/p98042us.ht ml. Diakses tgl. 17 Juni 2011
Anonim, 2011. Bacillius cereus. http://en.wikipedia.org/wiki/Bacillus cereus. Diakses 17 Juni 2011.

Badan Pusat Statisik dan Direktorat Jenderal Hortikultura, 2011. Produksi kol/kubis menurut provinsi, 2006-2010. http://www.bps.qo.id/sector/aqri/horti/index htmll\#methodologies.

Binoto, 2001. Isolasi dan uji patogenisitas Bacillius Cereus Frank. Serta daya bunuh kombinasinya dengan Sihalotrin terhadap Crocidolomia Binotalis Zell. (Lepidoptera:Pyralidae). Tesis Magister Pertanian. Universitas Gadjah Mada, Yogyakarta.

Gordon, R.E., W.C.Haynes \& C.H. Nay Pang., 1973. Th Genus Bacillus Agriculture Hand Book. No.427. United Stateds Department of Agriculture Washington D.C.

Hastuti, A.J. 2003. Kajian Biologi Ulat Krop Kubis (Crocidolomia binotalis Zell). (Lepidoptera:Pyralide) pada Tanaman Kubis, Sawi Hijau dan Sawi Putih. Skripsi. Fakultas Biologi Universitas Gadjah Mada, Yogyakarta. 
Harjaka, T. dan Suryanti. 2002. Kajian Beberapa Jamur Entomopatogenik pada Ulat Daun Kubis Hijau. Plutella xylostella. Jurnal Perlindungan Tanaman Indonesia. 8(2) : 94-99

Heimpel, A.M. and T.A. Angus. 1963. Disease Caused by Certain Sporeforming Bacteria. In. E.A. Steinhaus (Ed): Insect Pathology and Advanced Trastise. Vol. 2: Academic Press. New York.

Khetan, S.K. 2001. Microbial Pest Control. Marcell Dekker, Inc. USA.

Poinar.G.O. and G.M. Thomas., 1982. Diagnostik Manual for the Identification of Insect Pathogen. Plenum Press. New York.

Rueda, A. and A.M. Shelton. 2006. Diamondback Moth (DBM). www.nysaes.cornell. edu.htm. Diakses pada tanggal 12 April 2006.

Sembel, D.T, 2010. Pengendalian Hayati. Andi Offset, Yogyakarta.

Tay, L., K.T. Goh, S.E.Tan. 2008. An Outbreak of Bacillus cereus Food Poisoning. Singapore Medical Journal. 23(04) : 214217.

Untung, K. 2006. Pengantar Pengelolaan Hama Terpadu (edisi kedua). Gadjah Mada University Press, Yogyakarta.

Wikipedia, 2011. Hama plutella xylostella. Jurnal wikipedia Indonesia. Http://id.wikipedia. org/plutella xylostella. Diakses 17 Juni 2011.

Wikipedia, 2011. Bacillius cereus. Jurnal wikipedia Indonesia. Http://id.wikipedia.org/plutella xylostella. Diakses 17 Juni 2011. 